J. Dairy Sci. 92:365-368

doi:10.3168/jds.2008-1323

(c) American Dairy Science Association, 2009.

\title{
Short communication: Analysis of immune function in lactating dairy cows fed diets varying in phosphorus content
}

\author{
I. K. Mullarky, ${ }^{1}$ W. A. Wark, M. Dickenson, S. Martin, C. S. Petersson-Wolfe, and K. F. Knowlton \\ Department of Dairy Science, Virginia Polytechnic Institute and State University, Blacksburg 24061
}

\section{ABSTRACT}

The aim of this study was to evaluate the effect of varying dietary $\mathrm{P}$ on bovine immune function. Nine first- or second-lactation Holstein cows were fed diets varying in $\mathrm{P}$ in a $3 \times 3$ Latin square design. Diets were formulated to contain either low $(0.34 \%$, no supplementary P), medium $(0.43 \%)$, or high $(0.52 \%)$ P. All 3 diets were formulated to meet or exceed current NRC requirements for $\mathrm{P}$ content. Between d 21 and 26 of each period, blood samples were collected and serum inorganic $\mathrm{P}$ concentration, lymphocyte proliferation, and neutrophil bactericidal activity were measured. Serum $\mathrm{P}$ increased with increasing dietary $\mathrm{P}$ intake and was greatest in the first lactation compared with subsequent lactations. There was a stage of lactationdependent increase in lymphocyte proliferation after stimulation with concanavalin A, phytohemagglutinin, or pokeweed mitogen. However, dietary P did not alter lymphocyte proliferation or neutrophil bactericidal activity in vitro. In conclusion, decreasing dietary $\mathrm{P}$ to reduce manure $\mathrm{P}$ content and the risk of $\mathrm{P}$ losses from farms to surface water does not have an adverse effect on the innate or cell-mediated immune responses of lactating dairy cattle.

Key words: phosphorus, cattle, immune function

Excessive $\mathrm{N}$ and $\mathrm{P}$ entering streams and lakes can result in the overgrowth of algae and an overall decrease in water quality (Zhang and Fang, 2006). Field application of manure provides the $\mathrm{N}$ required by crops, but also results in the accumulation and runoff of $\mathrm{P}$ into nearby water sources (Toth et al., 2006). Reduction of P content in animal diets to meet NRC (2001) requirements effectively decreases excretory $\mathrm{P}$ and thus reduces buildup in the environment (Chapuis-Lardy et al., 2004).

Phosphorus, in the form of phosphate, is an essential mineral required for energy metabolism, maintenance, and function of skeletal structure, reproductive function, and lipid transport (Pond et al., 2005). In addition, modification of dietary $\mathrm{P}$ is linked with changes in

Received May 2, 2008.

Accepted September 4, 2008.

${ }^{1}$ Corresponding author: mullarky@vt.edu immune function in some species (Kegley et al., 2001; Jokinen et al., 2003). In the European whitefish, high-P diets correlated with an increase in plasma IgM (Jokinen et al., 2003). Increasing P in swine diets resulted in increased lymphocyte blastogenesis but decreased antibody response after injection of sheep red blood cells or ovalbumin (Kegley et al., 2001).

Current NRC (2001) requirements for lactating dairy cows range from 0.32 to $0.44 \% \mathrm{P}$, depending on milk production and DMI. Reducing dietary $\mathrm{P}$ is a commonly recommended best management practice to improve the ability of farmers to meet their nutrient management obligations (Knowlton et al., 2004). To our knowledge, no studies have evaluated the effect of lowering dietary $\mathrm{P}$ on bovine immune function. The main purpose of this study was to examine the effect of dietary $\mathrm{P}$ concentrations on the innate and cell-mediated immune responses of lactating dairy cattle.

All handling and experimentation were conducted under the approval of the Virginia Tech Institutional Animal Care and Use Committee. Holstein cows ( $\mathrm{n}=$ 9), housed at the Virginia Polytechnic Institute and State University Dairy Center, were fed diets for three 26 -d periods in a $3 \times 3$ Latin square design. At the beginning of the study, 4 cows were in their first lactation, 5 were in their second lactation, and all animals were between 5 and 112 DIM. The cows were fed a common control TMR for the first $4 \mathrm{~d}$ of each period and for at least $15 \mathrm{~d}$ between periods. During treatment periods, diets were formulated to contain low $(0.34 \%$, no supplemental P), medium $(0.43 \%)$, or high $(0.52 \%)$ concentrations of $\mathrm{P}$ (Tables 1 and 2). Cows were fed in Calan doors (American Calan, Northwood, NH) once daily at $1100 \mathrm{~h}$ to 5 to $10 \%$ excess of the intake of the previous day. Feed and water were offered ad libitum except during milking at 0700 and $1900 \mathrm{~h}$. Body weight and milk yield were recorded at each milking. Milk was sampled at the beginning of each treatment period, and all cows were found to be free of IMI, as assessed by microbiological analyses conducted according to National Mastitis Council (1999) guidelines. Blood was obtained from the jugular vein at the end of each period for isolation of mononuclear cells (d 22) and neutrophils (d 24). Serum organic P was measured from d 22 blood samples. 
Table 1. Ingredient composition of $\operatorname{diets}^{1}$

\begin{tabular}{|c|c|c|c|}
\hline Item & Low & Medium & High \\
\hline \multicolumn{4}{|l|}{ Ingredient, $\%$ of diet DM } \\
\hline Corn silage & 41.8 & 41.6 & 41.4 \\
\hline Grass legume silage & 8.3 & 8.2 & 8.2 \\
\hline Whole cottonseed & 3.0 & 3.0 & 3.0 \\
\hline Concentrate mixture & 46.9 & 47.1 & 47.3 \\
\hline \multicolumn{4}{|c|}{ Concentrate mixture, $\%$ of concentrate mixture DM } \\
\hline Corn meal & 48.2 & 47.2 & 46.3 \\
\hline Soybean meal ( $48 \% \mathrm{CP})$ & 30.8 & 30.8 & 30.8 \\
\hline Soybean hulls & 11.9 & 11.9 & 11.9 \\
\hline Sodium bicarbonate & 2.00 & 2.00 & 2.00 \\
\hline Ground limestone & 1.83 & 1.83 & 1.83 \\
\hline Tallow & 1.68 & 1.68 & 1.68 \\
\hline Megalac $^{2}$ & 1.50 & 1.50 & 1.50 \\
\hline Diamond-V $\mathrm{XP}^{3}$ & 0.500 & 0.50 & 0.500 \\
\hline Potassium-magnesium sulfate & 0.440 & 0.440 & 0.440 \\
\hline Salt (plain) & 0.400 & 0.400 & 0.400 \\
\hline Vitamin $\mathrm{A}-\mathrm{D}_{3}-\mathrm{E}$ premix $^{4}$ & 0.098 & 0.098 & 0.098 \\
\hline $0.06 \%$ Selenium premix ${ }^{5}$ & 0.050 & 0.050 & 0.050 \\
\hline $0.06 \%$ Organic selenium & 0.039 & 0.039 & 0.039 \\
\hline Vitamin $\mathrm{E}^{6}$ & 0.037 & 0.037 & 0.037 \\
\hline Trace mineral premix ${ }^{7}$ & 0.033 & 0.033 & 0.033 \\
\hline Mono ammonium phosphate & 0.00 & 1.19 & 2.39 \\
\hline Urea & 0.486 & 0.243 & 0.000 \\
\hline \multicolumn{4}{|c|}{${ }^{1}$ Treatments: low $(0.34 \%)$, medium $(0.43 \%)$, or high $(0.52 \%) \mathrm{P}$ as a percentage of dietary DM. } \\
\hline \multicolumn{4}{|c|}{${ }^{2}$ Church and Dwight Co. Inc., Princeton, NJ. } \\
\hline \multicolumn{4}{|c|}{${ }^{3}$ Diamond V Mills Inc., Cedar Rapids, IA. } \\
\hline \multirow{2}{*}{\multicolumn{4}{|c|}{$\begin{array}{l}{ }^{4} \text { Contained vitamin A, } 26,432 \mathrm{kIU} / \mathrm{kg} \text {; vitamin D, 8,811 kIU } / \mathrm{kg} \text {; and vitamin E, 44,053 mg } / \mathrm{kg} \text {. } \\
{ }^{5} \text { Contained Se, } 600 \mathrm{mg} / \mathrm{kg} \text {. }\end{array}$}} \\
\hline & & & \\
\hline \multicolumn{4}{|c|}{${ }^{6}$ Contained vitamin $\mathrm{E}, 132,159 \mathrm{mg} / \mathrm{kg}$. } \\
\hline \multicolumn{4}{|c|}{$\begin{array}{l}{ }^{7} \text { Contained Co, } 1,600 \mathrm{mg} / \mathrm{kg} ; \mathrm{Cu}, 40,000 \mathrm{mg} / \mathrm{kg} ; \mathrm{I}, 3,500 \mathrm{mg} / \mathrm{kg} ; \mathrm{Fe}, 30,000 \mathrm{mg} / \mathrm{kg} ; \mathrm{Mn}, 150,000 \mathrm{mg} / \mathrm{kg} \text {; and } \\
\mathrm{Zn}, 160,000 \mathrm{mg} / \mathrm{kg} \text {. }\end{array}$} \\
\hline
\end{tabular}

Serum was analyzed colorimetrically for inorganic P concentration (Beckman Analyzer PO4 Kit, 465145, Beckman Instruments, Fullerton, CA). Peripheral blood mononuclear cells were isolated on a FicollPaque density gradient $(1.077 \mathrm{~g} / \mathrm{mL}$; GE Healthcare, Piscataway, NJ), from whole blood collected using $40 \mathrm{mM}$ EDTA (10\% vol/vol) as described previously (Shafer-Weaver et al., 1996), and resuspended at $2 \times$ $10^{6}$ cells $/ \mathrm{mL}$ in RPMI-1640 containing $10 \%$ fetal bovine serum, and $0.02 \mathrm{mM}$ 2-mercaptoethanol (Sigma, St. Louis, MO). Lymphoproliferative responses of $2 \times 10^{5}$ cells/well were measured in triplicate after stimulation with $5 \mu \mathrm{g} / \mathrm{mL}$ of concanavalin A (Con A), $1 \mu \mathrm{g} / \mathrm{mL}$ of phytohemagglutinin (PHA), or $10 \mu \mathrm{g} / \mathrm{mL}$ of pokeweed mitogen (PWM). Background proliferation was determined with peripheral blood mononuclear cells cultured in RPMI-1640 supplemented with $10 \%$ fetal bovine serum. After incubating for $66 \mathrm{~h}$ at $37^{\circ} \mathrm{C}$, cell proliferation reagent (CellTiter 96-Aqueous, Promega, Madison, WI) was added and plates were read at 490 $\mathrm{nm}$ with a Bio-Tek microtiter well plate reader (BioTek Instruments Inc., Winooski, VT). Bovine neutrophils were isolated as described previously (Mullarky et al., 2001), and the ability to phagocytose Staphylococcus aureus strain ATCC 27217 was determined by using a bactericidal assay, as described previously (Aarestrup et al., 1994).

Statistical analysis of serum inorganic $\mathrm{P}$ and lymphoproliferative responses to PWM, PHA, and ConA were performed by using PROC MIXED (SAS Institute, Cary, NC) with a repeated measures approach. The appropriate error structure was assessed and used for each outcome variable. All outcome variables were evaluated for normality. A logarithmic transformation was applied to data not normally distributed. Independent variables included lactation number, stage of lactation, sampling time, and treatment. All variables were offered into the model and were removed by backward

Table 2. Chemical composition of $\operatorname{diets}^{1}$

\begin{tabular}{lccc}
\hline $\begin{array}{l}\text { Nutrient, } \\
\% \text { of dietary DM }\end{array}$ & Low & Medium & High \\
\hline CP & 16.0 & 15.7 & 15.3 \\
ADF & 18.7 & 18.9 & 19.0 \\
NDF & 31.8 & 32.3 & 32.7 \\
Ash & 7.50 & 7.50 & 7.49 \\
P & 0.34 & 0.43 & 0.52 \\
Ca & 0.80 & 0.79 & 0.79 \\
$\mathrm{Mg}$ & 0.25 & 0.25 & 0.25 \\
\hline
\end{tabular}

${ }^{1}$ Treatments: low $(0.34 \%)$, medium $(0.43 \%)$, or high $(0.52 \%) \mathrm{P}$ as a percentage of dietary DM. 
Table 3. The effect of dietary $\mathrm{P}$ on performance in 9 lactating Holstein cows ${ }^{1}$

\begin{tabular}{lccccc}
\hline Item & Low & Medium & High & SEM & Treatment, $P$-value \\
\hline DMI, kg/d & 22.6 & 24.0 & 21.2 & 1.25 & $<0.22$ \\
Milk yield, kg/d & 41.3 & 40.2 & 39.7 & 1.76 & $<0.46$ \\
BW, kg & 583 & 582 & 581 & 10.8 & $<0.89$ \\
P intake, g/d & $74.5^{\mathrm{a}}$ & $110.2^{\mathrm{b}}$ & $125.6^{\mathrm{c}}$ & 5.93 & $<0.01$ \\
\hline
\end{tabular}

${ }^{\mathrm{a}-\mathrm{c}}$ Values in the same row with different superscripts are significantly different $(P<0.05)$.

${ }^{1}$ Treatments: low $(0.34 \%)$, medium $(0.43 \%)$, or high $(0.52 \%) \mathrm{P}$ as a percentage of dietary DM.

elimination. All biologically plausible 2-way interaction terms were tested for significance. For each model, least squares means and standard errors were determined for significant variables. Significance was considered at $P$ $\leq 0.05$. To adjust for multiple comparisons within each model, Tukey's adjusted $P$-values were calculated for each variable. Once the final model was chosen, the residuals were checked for homoscedasticity, outliers, leverage cases, and normal distribution.

As shown previously, dietary P had no effect on DMI, milk yield, or BW (Table 3). However, decreasing the dietary $\mathrm{P}$ resulted in a significant decrease in concentration of inorganic $\mathrm{P}$ in the serum of lactating cows (Morse et al., 1992; Wu and Satter, 2000; Knowlton and Herbein, 2002). Cows on the low-P diet had significantly lower mean serum $\mathrm{P}(4.0 \pm 0.4 \mathrm{mg} / \mathrm{dL})$ than did cows fed the medium-P diet $(5.4 \pm 0.3 \mathrm{mg} / \mathrm{dL})$ or the high-P diet $(5.7 \pm 0.5 \mathrm{mg} / \mathrm{dL}$; Figure 1A). Overall, serum inorganic $\mathrm{P}$ concentrations were within the normal range (4 to $8 \mathrm{mg} / \mathrm{dL}$; Forar et al., 1982), although some individual cows on the low-P diet were below that range. Even though serum inorganic $\mathrm{P}$ concentration reflects $\mathrm{P}$ intake, the influence of other dietary deficiencies (e.g., Ca, vitamin D) that stimulate bone resorption (Ternouth, 1990), and therefore serum $\mathrm{P}$, make this an inadequate measure of cow $\mathrm{P}$ status. As shown previously (Forar et al., 1982), there was a significant effect $(P<0.05)$ of lactation number on serum $\mathrm{P}$, with firstlactation animals $(5.3 \pm 0.3 \mathrm{mg} / \mathrm{dL})$ displaying greater serum $\mathrm{P}$ concentration compared with second-lactation animals $(4.3 \pm 0.23 \mathrm{mg} / \mathrm{dL})$, regardless of diet.

Because more definitive assessment of the $\mathrm{P}$ status of cows fed diets varying in $\mathrm{P}$ content would require measurement of $\mathrm{P}$ excretion (not measured), and because $\mathrm{P}$ absorption varies with dietary levels, calculation of $\mathrm{P}$ balances may provide results that are substantially different from actual values of $\mathrm{P}$. Therefore, $\mathrm{P}$ balances were not estimated and only values for dietary $\mathrm{P}$ concentration and total intake are presented (Table $3)$. In this study, $\mathrm{P}$ intake was significantly $(P<0.01)$ increased with increasing dietary $\mathrm{P}$ (Table 3 ).

The effect of $\mathrm{P}$ intake on lymphocyte proliferation was evaluated by stimulating mononuclear cells with
Con A, PWM, or PHA. There were no significant effects of dietary $\mathrm{P}$ on lymphocyte proliferation in response to mitogen stimulation (Figure 1B). Kegley et al. (2001) reported increased lymphocyte proliferation in response to PHA, but not PWM, with increasing supplemental P in swine diets. Furthermore, Kegley et al. (2001) suggested that increased plasma 1,25-dihydroxyvitamin $\mathrm{D}_{3}$ concentrations would decrease macrophage function and subsequent lymphocyte proliferation in pigs fed low-P diets. According to Peterson et al. (2005), dietary $\mathrm{P}$ had no effect on plasma 1,25-dihydroxyvitamin $\mathrm{D}_{3}$ concentrations in cows and would therefore not affect macrophage function, which would explain the lack of response in this study.

There was a significant effect of stage of lactation on lymphocyte proliferation in response to Con A $(P<0.01)$, PHA $(P=0.02)$, and PWM $(P<0.01)$, with greater proliferation percentages (Con A: $270.3 \pm 37.8$; PHA: $192.6 \pm 26.1$; and PWM: $160.8 \pm 15.7)$ in early-lactation cows (9 to $60 \mathrm{DIM} ; \mathrm{n}=6$ ) as compared with $60+$ DIM ( $\mathrm{n}=21$; Con A: $56.5 \pm 3.4$; PHA: $40.3 \pm 2.9$; and PWM: $46.1 \pm 2.5)$. Previous research has suggested that there is an increase in percentage of peripheral CD8 cells in midlactation ( $>90 \mathrm{~d}$ postpartum) as compared with early lactation (<90 d postpartum; Park et al., 1992). The CD8 population consists of suppressor cells that decrease the responsiveness of lymphocyte populations (Shafer-Weaver and Sordillo, 1997). Together with our results, this suggests the possibility of an increase in suppressor CD8 populations that correlates with an increase in DIM.

Neutrophil bactericidal activity against Staph. aureus was assessed. There was no significant effect of dietary $\mathrm{P}$ concentration on the ability of bovine neutrophils to kill bacteria in vitro (Figure 1C). Although phosphate depletion is linked with decreased phagocytosis because of the requirement for ATP by PMN (Craddock et al., 1974; Kiersztejn et al., 1992), the lowest P diet in this study may not have been low enough to affect ATP adversely. In conclusion, we show here that a decrease of dietary $\mathrm{P}$ to amounts recommended by the NRC (2001) resulted in a decreased P serum concentration, but did not alter the innate or cell-mediated immune responses of lactating dairy cattle. 

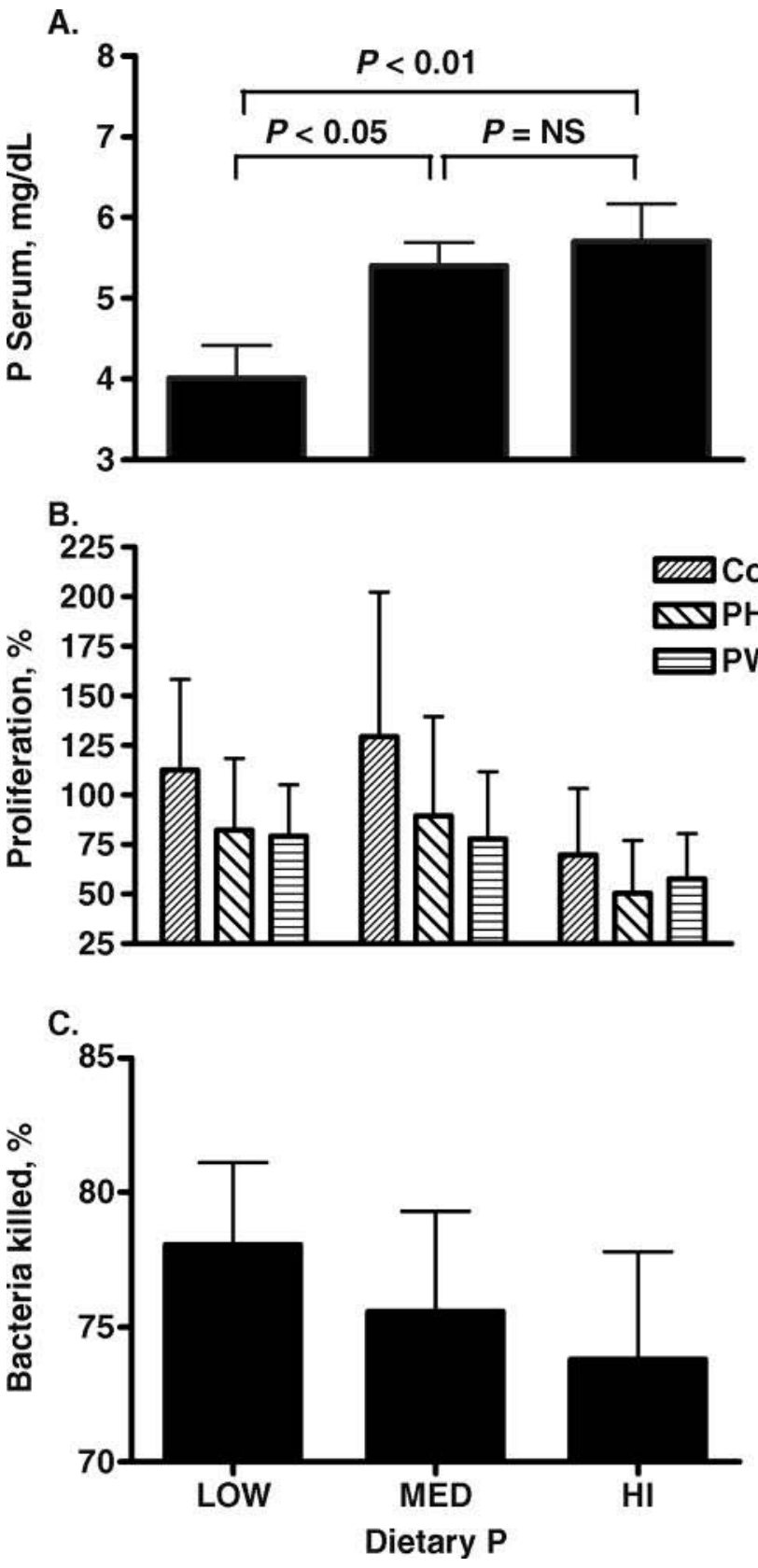

Figure 1. The effect of dietary $\mathrm{P}$ on bovine immune function. Increasing concentrations of dietary $\mathrm{P}$ resulted in a significant increase in serum P levels (A) but had no significant effect on bovine lymphocyte proliferation (B) in response to mitogen [concanavalin A (ConA), phytohemagglutinin (PHA), or pokeweed mitogen (PWM)] stimulation or on neutrophil bactericidal function (C). Treatments: low (0.34\%), medium $(0.43 \%)$, or high $(0.52 \%) \mathrm{P}$ as a percentage of dietary DM.

\section{REFERENCES}

Aarestrup, F. M., N. L. Scott, and L. M. Sordillo. 1994. Ability of Staphylococcus aureus coagulase genotypes to resist neutrophil bactericidal activity and phagocytosis. Infect. Immun. 62:56795682 .
Chapuis-Lardy, L., J. Fiorini, J. Toth, and Z. Dou. 2004. Phosphorus concentration and solubility in dairy feces: Variability and affecting factors. J. Dairy Sci. 87:4334-4341.

Craddock, P. R., Y. Yawata, L. VanSanten, S. Gilberstadt, S. Silvis, and H. S. Jacob. 1974. Acquired phagocyte dysfunction. A complication of the hypophosphatemia of parenteral hyperalimentation. N. Engl. J. Med. 290:1403-1407.

Forar, F. L., R. L. Kincaid, R. L. Preston, and J. K. Hillers. 1982. Variation of inorganic phosphorus in blood plasma and milk of lactating cows. J. Dairy Sci. 65:760-763.

Jokinen, E. I., J. Vielma, T. M. Aaltonen, and J. Koskela. 2003. The effect of dietary phosphorus deficiency on the immune responses of European whitefish (Coregonus lavaretus L.). Fish Shellfish Immunol. 15:159-168.

Kegley, E. B., J. W. Spears, and S. K. Auman. 2001. Dietary phosphorus and an inflammatory challenge affect performance and immune function of weanling pigs. J. Anim. Sci. 79:413-419.

Kiersztejn, M., I. Chervu, M. Smogorzewski, G. Z. Fadda, J. M. Alexiewicz, and S. G. Massry. 1992. On the mechanisms of impaired phagocytosis in phosphate depletion. J. Am. Soc. Nephrol. 2:1484-1489.

Knowlton, K. F., and J. H. Herbein. 2002. Phosphorus partitioning during early lactation in dairy cows fed diets varying in phosphorus content. J. Dairy Sci. 85:1227-1236.

Knowlton, K. F., J. S. Radcliffe, C. L. Novak, and D. A. Emmerson. 2004. Animal management to reduce phosphorus losses to the environment. J. Anim. Sci. 82(E Suppl.):E173-E195.

Morse, D., H. H. Head, C. J. Wilcox, H. H. van Horn, C. D. Hissem, and B. Harris Jr. 1992. Effects of concentration of dietary phosphorus on amount and route of excretion. J. Dairy Sci. 75:3039-3049.

Mullarky, I. K., C. Su, N. Frieze, Y. H. Park, and L. M. Sordillo. 2001. Staphylococcus aureus agr genotypes with enterotoxin production capabilities can resist neutrophil bactericidal activity. Infect. Immun. 69:45-51.

National Mastitis Council. 1999. Laboratory Handbook on Bovine Mastitis. Rev. ed. Natl. Mastitis Counc. Inc., Madison, WI.

NRC. 2001. Nutrient Requirements of Dairy Cattle. 7th rev. ed. Natl. Acad. Press, Washington, DC.

Park, Y. H., L. K. Fox, M. J. Hamilton, and W. C. Davis. 1992. Bovine mononuclear leukocyte subpopulations in peripheral blood and mammary gland secretions during lactation. J. Dairy Sci. 75:998-1006.

Peterson, A. B., M. W. Orth, J. P. Goff, and D. K. Beede. 2005. Periparturient responses of multiparous Holstein cows fed different dietary phosphorus concentrations prepartum. J. Dairy Sci. 88:3582-3594

Pond, W. G., D. C. Church, K. R. Pond, and P. A. Schoknecht. 2005. Basic Animal Nutrition and Feeding. 5th ed. John Wiley and Sons Inc., Hoboken, NJ.

Shafer-Weaver, K. A., G. M. Pighetti, and L. M. Sordillo. 1996. Diminished mammary gland lymphocyte functions parallel shifts in trafficking patterns during the postpartum period. Proc. Soc. Exp. Biol. Med. 212:271-280.

Shafer-Weaver, K. A., and L. M. Sordillo. 1997. Bovine CD8 suppressor lymphocytes alter immune responsiveness during the postpartum period. Vet. Immunol. Immunopathol. 56:53-64.

Ternouth, J. H. 1990. Phosphorus and beef production in Northern Australia. 3. Phosphorus in cattle-A review. Trop. Grassl. $24: 159-169$.

Toth, J. D., Z. Dou, J. D. Ferguson, D. T. Galligan, and C. F. Ramberg Jr. 2006. Nitrogen- vs. phosphorus-based dairy manure applications to field crops: Nitrate and phosphorus leaching and soil phosphorus accumulation. J. Environ. Qual. 35:2302-2312.

Wu, Z., and L. D. Satter. 2000. Milk production and reproductive performance of dairy cows fed two concentrations of phosphorus for two years. J. Dairy Sci. 83:1052-1063.

Zhang, M. K., and L. P. Fang. 2006. Phosphorus accumulation and eutrophication in feed-supply freshwater fishponds. J. Environ. Sci. (China) 18:816-821. 